\title{
Assessment of Complex Free Form Surfaces with Surface Profile Deviation
}

\author{
Miroslav Dovica ${ }^{1}$, Ján Buša ${ }^{2}$, Emil Spišák ${ }^{1}$, Michal Fabian ${ }^{1}$, Peter Ižol ${ }^{1}$, Jana Fabianová ${ }^{3}$ \\ ${ }^{1}$ Faculty of Mechanical Engineering, Technical University of Košice, Letná 9, Košice, 040 01, Slovakia. E-mail: miro- \\ slav.dovica@tuke.sk, emil.spisk@tuke.sk,michal.fabian@tuke.sk,peter.ižol@tuke.sk \\ ${ }^{2}$ Faculty of Electrical Engineering and Informatics, Technical University of Košice, Letná 9, Košice, 040 01, Slovakia. \\ E-mail: jan.busa@tuke.sk \\ ${ }^{3}$ Faculty of Mining, Ecology, Process Control and Geotechnology, Technical University of Košice, Letná 9, Košice, 040 \\ 01, Slovakia.jana.fabianova@tuke.sk
}

\begin{abstract}
Accuracy of work-pieces of complex free form surfaces is achieved by tolerancing, producing and metrology of workpieces. The tolerance zone is defined by form tolerances, their orientation and location on the work-pieces. Tolerances for complex form surfaces are specified by line profile tolerance or surface profile tolerance. These tolerances control form or combination of size, form, orientation and location. In a machining process the impact of machining parameter settings on the final surface quality will be researched. The influence of toolpaths in connection with the SH (Scallop Height) parameter setting on production accuracy and quality of machined surface will be compared. For geometry verification of the complex form surfaces are coordinate measurements used. The measurement area is modeled with the equations in CATIA V5. The data of machined surface obtained through the contact coordinate measurement are processed using the coordinate system adjustment via the RSS minimization by the Newton method in Matlab/Octave. Calculated values of surface profile deviations at individual machining strategies are used to achieve the required quality of machined surface through optimization of the machining parameters.
\end{abstract}

Keywords: coordinate measurement, form tolerances, complex surfaces, Newton method, orthogonal deviation

\section{Acknowledgements}

This work is a part of these projects VEGA 1/0182/15, VEGA 1/0198/15, KEGA 014STU-4/2015, KEGA 021TUKE4/2015.

\section{References}

[1] MEHRAD, V., XUE, D., GU, P. (2013). Prediction of surface reconstruction uncertainties for freeform surface inspection, Measurement, vol. 46, no. 8, pp. 2682-2694, Oct.

[2] OHARA, M., HIGASHI, M. (1983). Integration of CAD/CAM systems in automotive body engineering, Computers \& Graphics, vol. 7, no. 3-4, pp. 307-314, 1983.

[3] SITNIK, R., BŁASZCZYK, P. M. (2012). Segmentation of unsorted cloud of points data from full field optical measurement for metrological validation, Computers in Industry, vol. 63, no. 1, pp. 30-44, Jan. 2012.

[4] KRUTH, J. P., KERSTENS, A. (1998). Reverse engineering modelling of free-form surfaces from point clouds subject to boundary conditions," Journal of Materials Processing Technology, vol. 76, no. 1-3, pp. 120-127, Apr. 1998.

[5] OE, T., SHIZUKI, B., TANAKA, J. (2012). Scan modeling: 3D modeling techniques using cross section of a shape, in 10th Asia-Pacific Conference on Computer-Human Interaction, APCHI 2012, 2012, pp. $243-250$.

[6] WU, N., YANG, C., GUO, R., ZHANG, Z., ZHOU, C., CHEN, W., TAO, L. (2011). Reverse design and manufacture of the car door using reverse engineering methods, in ICCTP 2011: Towards Sustainable Transportation Systems - Proceedings of the 11th International Conference of Chinese Transportation Professionals, 2011, pp. 3849-3854.

[7] VARADY, T., MARTIN, R. (2002). Chapter 26 - Reverse Engineering, in Handbook of Computer Aided Geometric Design, G. Farin, J. Hoschek, M.-S. Kim, and M.-S. B. T.-H. of C. A. G. D. Kim, Eds. Amsterdam: NorthHolland, 2002, pp. 651-681.

[8] D. HANSFORD, D., FARIN, G. (2002). Chapter 7 - Curve and Surface Constructions, in Handbook of Computer Aided Geometric Design, G. Farin, J. Hoschek, M.-S. Kim, and M.-S. B. T.-H. of C. A. G. D. Kim, Eds. Amsterdam: North-Holland, 2002, pp. 165-192. 
[9] CHOI, B. K., KIM, B. H., JERARD, R. B. (2002). Chapter 22 - Sculptured Surface NC Machining, in Handbook of Computer Aided Geometric Design, G. Farin, J. Hoschek, M.-S. Kim, and M.-S. B. T.-H. of C. A. G. D. Kim, Eds. Amsterdam: North-Holland, 2002, pp. 543-574.

[10] ALTAN, T., LILLY, B., YEN, Y. C. (2001). Manufacturing of Dies and Molds, CIRP Annals - Manufacturing Technology, vol. 50, no. 2, pp. 404-422, 2001.

[11] LO, C. C. (2000). CNC machine tool surface interpolator for ball-end milling of free-form surfaces, International Journal of Machine Tools and Manufacture, vol. 40, no. 3, pp. 307-326, Feb. 2000.

[12] WEI, E. J., LIN, M. C. (2005). Study on general analytical method for CNC machining the free-form surfaces, Journal of Materials Processing Technology, vol. 168, no. 3, pp. 408-413, Oct. 2005.

[13] YOO, D. J. (2011). Three-dimensional surface reconstruction of human bone using a B-spline based interpolation approach, CAD Computer Aided Design, vol. 43, no. 8, pp. 934-947, 2011.

[14] KALRA, A. (2011). Three-dimensional modeling of femoral bone of human body and its failure analysis for hip resurfacing, International Journal of Applied Engineering Research, vol. 6, no. 4, pp. 445-451, 2011.

[15] SAlMI, M., TUOMI, J., PALOHEIMO, K. S., BJÖRKSTRAND, R., PALOHEIMO, M., SALO, J., KONTIO, R., MESIMÄKI, K., MÄKITIE, A. A. (2012). Patient-specific reconstruction with 3D modeling and DMLS additive manufacturing, Rapid Prototyping Journal, vol. 18, no. 3, pp. 209-214, 2012.

[16] FANG, D., ZHANG, A., QIU, Y. (2013). Research and practice on new measuring and drafting mode of mechanical drawing based on reverse engineering, 2012 International Conference on Measurement, Instrumentation and Automation, ICMIA 2012, vol. 239-240. School of Mechanical Engineering, Zhengzhou University, Zhengzhou, 450001, China, pp. 645-648, 2013.

[17] Herlin, C., DOUCET, J. C., BIGORRE, M., KHELIFA, H. C., CAPTIER, G. (2013). Computer-assisted midface reconstruction in Treacher Collins syndrome part 1: Skeletal reconstruction, Journal of Cranio-Maxillofacial Surgery, vol. 41, no. 7, pp. 670-675, 2013.

[18] LI, J., LI, P., LU, H., SHEN, L., TIAN, W., LONG, J., TANG, W. (2013). Digital design and individually fabricated titanium implants for the reconstruction of traumatic zygomatico-orbital defects, Journal of Craniofacial Surgery, vol. 24, no. 2, pp. 363-368, 2013.

[19] PONIATOWSKA, M. (2012). Deviation model based method of planning accuracy inspection of free-form surfaces using CMMs, Measurement: Journal of the International Measurement Confederation, vol. 45, no. 5, pp. 927-937, 2012.

[20] LEE, R. T., SHIOU, F. J. (2011). Multi-beam laser probe for measuring position and orientation of freeform surface, Measurement: Journal of the International Measurement Confederation, vol. 44, no. 1, pp. 1-10, 2011.

[21] KALE, K. B., GURUMOORTHY, B. (2013). Profile Tolerance Verification for Free-form Surfaces Using Medial Axis Transform, Procedia CIRP, vol. 10, no. 0, pp. 133-141, 2013.

[22] Dimensional metrology portal, In: www.tuke.sk/smetrologia [Online], Available: $<$ http://web.tuke.sk/smetrologia/15.html>, [Accessed: 18-March-2016]

[23] FARIN, G., HOSCHEK, J., KIM, M. S. (2002). Handbook of Computer Aided Geometric Design, North-Holland, Amsterdam, 2002.

[24] DVǑ̌ÁČKOVÁ, Š. (2016). Gauge Block Calibration by Interferometry, In: Manufacturing Technology, 2016, Vol. 16, No. 1.pp. 58 - 63, ISSN 1213-2489

[25] JENČURÁKOVÁ, D., PALENČÁR, R. (2016). Optimizing Management of the Measurement System of the Technological Process“", Š. Dvořáčková, "Gauge Block Calibration by Interferometry, In: Manufacturing Technology, 2016, Vol. 16, No. 1.pp. 107 - 113, ISSN 1213-2489

[26] TICHÁ, Š., SRBA, O., VAVŘINA, J. (2016). A Measuring Device for the Checking of 3D Indicators, In: Manufacturing Technology, 2016, Vol. 16, No. 1. pp. 280 - 284, ISSN 1213-2489 